\title{
PENGARUH POSTUR MOTIVASI DITINJAU \\ DARI COMMITMENT, CAPITULATION, RESISTANCE, DISENGAGEMENT DAN GAME PLAYING TERHADAP KEPATUHAN WAJIB PAJAK ORANG PRIBADI
}

\author{
Agus Taufiq \\ STIE PGRI Dewantara Jombang \\ E-mail: agustaufik.stiepgridw@gmail.com
}

\begin{abstract}
This research aims to find out the influence of motivation postur and education level to the personal obligation tax loyalt of report SPT. Sampling of this research as many as 66 personal obligation tax who has small industrial.The Multiple regressionanalytic show upof motivation postur consist of capitulation, resistance, disengagement and game playing, also education level doesn't influence partialy of report SPT. However commitment give as partial influence personal obligation tax loyalty of report SPT. But, simultanly all of variable didn't influence the personal obligation tax loyalty of report SPT.
\end{abstract}

Keywords: Motivation Postur, Education Level, Obligation tax loyalty

\section{A. Pendahuluan}

Pajak mempunyai peranan penting dalam kehidupan bernegara, tidak hanya berfungsi sebagai sumber pendapatan namun juga memiliki fungsi distribusi pendapatan. Pajak Penghasilan orang pribadi merupakan salah satu instrumen untuk mengatasi ketimpangan distribusi pendapatan di masyarakat. Kemiskinan, baik relatif maupun mutlak, akan 
menimbulkan beberapa kendala bagi peningkatan kesejahteraan masyarakat suatu negara. Kesenjangan sosial di masyarakat dapat menyebabkan ketidakstabilan politik dan ekonomi negara. Sehingga kesulitan yang dialami oleh anggota masyarakat termiskin pada akhirnya dirasakan oleh seluruh masyarakat. (http://www.pajak.go.id/ 21 Agustus 2012 $17: 25)$.

Menurut

Departemen Keuangan(www.fiskal.depkeu.go.id), peran pajakdalam membiayai pembangunan tercermindari sumber penerimaan Anggaran Pendapatan danBelanja Negara (APBN) tahun 2013 yang $77,9 \%$ bersumber daripenerimaan pajak. Dengan demikian, pemerintah dalam hal ini DirektoratJenderal Pajak telah melakukan berbagai upayaguna memaksimalkan penerimaan pajak. Salahsatu upaya tersebut adalah melaluireformasi peraturan perundang-undangan di bidangperpajakan dengan diberlakukannya selfassessment system dalam pemungutan pajak sejaktahun fiskal 1984.

Menurut Dudi Wahyudi (2007) yang dikutip dari Susi Dianawati (2008), pelaksanaan sistem self assessment harus didukung oleh tingkat kesadaran dan kepatuhan wajib pajak. Namun tingkat kesadaran dan kepatuhan pajak di Indonesia saat ini sangat rendah .Hal ini tersebut dapat dibuktikan dari tabel berikut ini:

Tabel. 1.1 Rasio Kepatuhan Wajib Pajak Melaporkan SPT Tahunan

\begin{tabular}{|l|r|r|r|r|r|}
\hline \multicolumn{1}{|c|}{ Penjelasan } & \multicolumn{1}{c|}{2008} & \multicolumn{1}{c|}{2009} & \multicolumn{1}{c|}{2010} & \multicolumn{1}{c|}{2011} & \multicolumn{1}{c|}{2012} \\
\hline Wajb Pajak Terdaftar Wajb Lapor SPT & $6,341,828$ & $9,996,620$ & $14,101,933$ & $17,694,317$ & $17,659,278$ \\
\hline SPT Tahunan PPh & $2,097,849$ & $5,413,114$ & $8,202,309$ & $9,332,626$ & $9,482,480$ \\
\hline Rasio Kepatuhan & $33.08 \%$ & $54.15 \%$ & $5816 \%$ & $52.74 \%$ & $53.70 \%$ \\
\hline
\end{tabular}

Sumber : www.otax.com

Perilaku kepatuhan wajib pajak dipengaruhi oleh banyak faktor. Misu (2011) membagi kepatuhan pajak dalam dua faktor besar yaitu faktor ekonomi dan non ekonomi.Faktor 
ekonomi meliputithe level of actual income, tax rates, tax benefits, penalties, tax audits, fines, audit probability. Sedangkan faktor non ekonomi meliputiattitude toward taxes, personal, social and national norms, dan perceived fairness of tax system. Motivasi juga merupakan faktor yang mempengaruhi kepatuhan pajak. Hasil penelitian Alm (2013), menyebutkan bahwa keputusan kepatuhan wajib pajak dipengaruhi oleh utilitas yang akan diperoleh dengan adanya insentif keuangan.Insentif keuangan dibentuk oleh sanksi dan denda perpajakan, pemeriksaan pajak dan tarif pajak. Wajib pajak tidak selalu berperilaku dalam pandangan teori kriminologi ekonomi di atas, seperti egois, rasional, mementingkan diri sendiri, melainkan sering termotivasi oleh banyak faktor lain seperti norma sosial, moralitas, altruisme, dan keadilan.

Penelitian yang dilakukanBraithwaite, Murphy, and Reinhart (2007) menggunakan indikator postur motivasi (motivational posture) untuk mengetahui motivasi wajib pajak dalam memenuhi kepatuhan pajak. Postur motivasi menjelaskan sikap wajib pajak yang harus dikelola ketika fiskus membutuhkan perubahan atau penjelasan atas suatu perilaku pajak. Perilaku pajak tersebut antara lain adalah tidak menyampaikan surat pemberitahuan tahunan(SPT), tidak melaporkanpendapatan dalam SPT, keterlibatan dalam shadow economy, atau tidak melaporkan biaya sesungguhnya.

Cara pandang atau evaluasi wajib pajak terhadap fiskus tampak dalam lima postur motivasi yang diidentifikasikan dalam penelitian ini adalah 1) commitment, 2) capitulation, 3) resistance, 4) disengagement dan 5) game playing. Commitment adalah tingkatan ketika wajib pajak secara sadar atas kehendak pribadiuntuk merasa terlibat dengan misi otoritas pajak sebagai regulator.Capitulation menggambarkan individu yang menerima berbagai aturan dari otoritas pajak tanpa harus merasa memiliki keterlibatan. Sedangkan Resistance adalah suatu perlawanan terbuka terhadap otoritas pajak.Disengagement menunjukkan keterpisahan psikologis wajib pajak dari otoritas pajak serta game playing mewakili 
perilaku dan praktik untuk menghindar dari ketentuan dengan cara "memainkan aturan".

Torgler and Schneider (2005:231) menyebutkan bahwa faktor kepatuhan wajib pajak di Austria juga dipengaruhi oleh motivasi instrinsik yaitu faktor moral. Variabel kepercayaan atau kebanggaan yang mempengaruhi moral wajib pajak sehingga diidentifikasi sebagai faktor penentu utama yang membentuk semangat kepatuhan pajak wajib pajak di Austria.

Namun, di sisi lain wajib pajak tetap ingin memanfaatkan celah dalam peraturan perpajakan yang memungkinkan pembayaran pajak minimal atau yang biasa disebut sebagai perencanaan pajak. Dengan demikian kepatuhan wajib pajak bukan hanya didasarkan pada faktor ekonomi tersebut, tetapi juga faktor-faktor non ekonomi, seperti motivasi, norma sosial, dan etika. Salah satu faktor motivasi yang diduga berpengaruh terhadap kepatuhan wajib pajak dapat dilihat dengan mempertimbangkan postur motivasi.

Senada dengan penelitian Susi (2008) menunjukkan bahwa motivasi dan tingkat pendidikan secara bersama-sama (silmutan) berpengaruh secara signifikan sebesar $37 \%$ terhadap kepatuhan wajib pajak. Sedangkan sisanya $63 \%$ dijelaskan oleh variabel lain. Penelitian Mangoting (2013) menunjukkan bahwa postur motivasi berupa variabel commitment, capitulation, resistance dan disengagement secara parsial tidak mempengaruhi kepatuhan wajib pajak orang pribadi dalam melaksanakan kepatuhan pajak. Variabel game playing secara parsial mempengaruhi kepatuhan wajib pajak orang pribadi. Namun faktor postur motivasi secara simultan mempengaruhi kepatuhan wajib pajak orang pribadi.

Berdasarkan penelitian sebelumnya, penelitian ini dilakukan untuk mengetahui pengaruh postur motivasi dan tingkat pendidikan terhadap kepatuhan wajib pajak orang pribadi. 


\section{B. Landasan Teori}

\section{Perpajakan}

Salah satu sumber utama penerimaan negara berasal dari sektor pajak.Pajak merupakan iuran wajib yang harus dibayarkan oleh warga negara tanpa adanya timbal balik secara langsung.Pajak adalah prestasi yang dipaksakan sepihak oleh dan terutang kepada pengusaha (menurut norma-norma yang ditetapkan secara umum), tanpa adanya kontraprestasi, dan semata-mata digunakan untuk menutup pengeluaranpengeluaran umum."(Feldmanndalam Waluyo2011). Menurut Prof. Dr. MJH. Smeets dalam De Economische Betekeis Belastingen dalam buku Thomas Sumarsan, (2010:3)“Pajak adalah prestasi kepada pemerintah yang terutang melalui norma-norma umum dan yang dapat dipaksakannya, tanpa adaya kontraprestasi yag dapat ditunjukkan dalam hal individual, dimaksudkan untuk membiayai pegeluaran pemerintah."

Dengan demikian dapat disimpulkan bahwa pajak dipungut berdasarkan undang-undang serta aturan pelaksanaannya yang sifatnya dapat dipaksakan, tidak adanya kontraprestasi idividual oleh pemerintah, dipungut oleh negara baik pemerintah pusat maupun daerah, diperuntukkan bagi pengeluaran pemerintah, serta pajak sebagai sarana mengatur dan mengendalikan fiskal.

Menurut Waluyo (2011:13) pajak dapat ditinjau dari berbagai aspek ekonomi, hukum, keuangan dan sosiologi. Berdasar sudut pandang ekonomi, pajak merupakan penerimaan negara yang digunakan untuk mengarahkan kehidupan masyarakat menuju kesejahteraan.Dilihat dari kaca mata hukum, pajak bersifat mengikat dan memaksa.Sudut pandang keungan menjadikan pajak sebagai salah satu suber utama penerimaan negara selain migas.Sedangkan berdasarkan sudut pandang sosiologi, pungutan pajak harus mampu memberikan dampak positif bagi masyarakat.

Sebagai komponen fiskal yang utama, keberadaan pajak sangat penting sekali.Pajak memiliki fungsi utama budgeter sekaligus reguler.Fungsi budgeter terkait dengan keberadaan 
pajak sebagai salah satu komponen utama dalam penerimaan APBN sedangkan sebagai fungsi reguler pajak sebagai alat untuk melaksanakan kebijakan di bidang sosial dan ekonomi.

Secara umum, pajak menurut golongan pembebanan dibedakan menjadi pajak langsung dan pajak tidak langsung.Sedangkan menurut sifat pajak dibedakan menjadi pajak subjektif, dan pajak objektif.Dilihat dari sudut pandang pemungutnya, pajak dibedakan menjadi pajak pusat dan pajak daerah.

Menurut UU No. 28 Tahun 2007 Pasal 1 menyebutkan definisi Wajib Pajak adalah orang pribadi atau badan yang menurut ketentuan peraturanperundang-undangan perpajakan ditentukan untuk melakukan kewajiban perpajakan,termasuk pemungut pajak atau pemotong pajak tertentu.Wajib pajak tersebut wajib mendaftarkan diri untuk memperoleh Nomor Pokok Wajib Pajak (NPWP) ke kantor pelayanan pajak yang wilayah kerjanya meliputi tempat tinggal atau kedudukanwajib pajak. Wajib pajak secara umum dibedakan menjadi dua, yaitu wajib pajak terdaftar dan wajib pajak non efektif. UU No. 28 tahun 2007 menyebutkan bahwa wajib pajak terdaftar adalah wajib pajak yang telah terdaftar dalam tata usaha Kantor Pelayanan Pajak dan telah diberikan NPWP.Sedangkan wajib pajak non efektif dijelaskan dalam Surat EdaranNo. SE89/PJ/2009adalah wajibpajak yang tidak melakukan pemenuhan kewajiban perpajakannya baik berupapembayaran maupun penyampaian SPT Masadan/atau SPT Tahunan sesuai dengan ketentuanperaturan perundang-undangan perpajakan, yang nantinya dapat diaktifkan kembali.

Wajib Pajak dinyatakan sebagai WP NE apabila memenuhi salah satu kriteria sebagai berikut:

a) Selama 3 (tiga) tahun berturut-turut tidak pernah melakukan pemenuhan kewajiban perpajakan baik berupa pembayaran pajak maupun penyampaian SPT Masa dan/atau SPT Tahunan.

b) Tidak diketahui/ditemukan lagi alamatnya. 
c) Wajib pajak orang pribadi yang telah meninggal dunia tetapi belum diterima pemberitahuan tertulis secara resmi dari ahli warisnya atau belum mengajukan penghapusan NPWP.

d) Secara nyata tidak menunjukkan adanya kegiatan usaha.

e) Bendahara tidak melakukan pembayaran lagi.

f) Wajib pajak badan yang telah bubar tetapi belum ada Akte Pemburannya atau belum ada penyelesaian likuidasi (bagi badan yang sudah mendapat pengesahan dari instansi yang berwenang).

g) Wajib pajak orang pribadi yang bertempat tinggal atau berada atau bekerja di luar negeri lebih dari 183 dalam jangka waktu 12 (dua belas) bulan.

Pajak penghasilan menurut Waluyo (2011:213)adalahpajak yang dikenakan atas penghasilan dari kegiatan aktif (active income) mupun bersumberkan penghasilan pasif.Sedangkan pihak yang dikenakan pajak penghasilan disebut dengan istilah subjek pajak penghasilan yang meliputisubjek pajak dalam negeri dan subjek pajak luar negeri.

\section{Postur Motivasi}

Pemerintah harus menyadari bahwa faktor ekonomi dalam meningkatkan kepatuhan pajak seperti tarif pajak, sanksi dan denda administrasi seharusnya tidak lagi menjadi fokus utama untuk meningkatkan kepatuhan wajib. Meskipun pemerintah mempunyai legitimasi hukum untuk memaksa wajib pajak, tetapi pemerintah tidak mempunyai legitimasi psikologi. Dengan demikian diperlukan adanya pendekatan baru dalam rangka meningkatkan kepatuhan pajak.Pada sisi lain, masyarakat akan memberikan evaluasi terhadap pemerintah, dalam hal ini fiskus, guna melihat bagaimana keberpihakan fiskus atau kinerja fiskus, yang pada akhirnya akan membentuk jarak antara wajib pajak dan fiskus. Bogardus yang dikutip oleh Braithwaite (2007:138) menyebut jarak ini sebagai jarak sosial (social distance). 
Jarak sosial tercipta saat individu atau kelompok memilihmendekat, mendukung, sejalan dengan fiskus atau justru menjauh, menghindari kontak dengan fiskus. Jarak yang tercipta pertama kali mungkin merupakan sebuah intuisi, namun tidak dalam jangka panjang. Wajib pajak akan mengartikulasikan keyakinan, mengembangkan rasionalisasi intuisi serta menggunakan nilai dan ideologi untuk menempatkan diri, menjaga jarak dengan fiskus. Gabungan antara keyakinan dan perilaku yang saling terkait dibagikan, dipertanyakan, diuji, dan menjadi bagian dari kehidupan sosial sebuah komunitas. Gabungan dari kepercayaan, sikap, preferensi, minat, dan perasaan yang secara simultan akan mengkomunikasikan sejauh mana wajib pajak bersikap fiskus inilah yang dikenal sebagai postur motivasi.

Menurut Braithwaite (2007), postur motivasi adalah sinyal sosial yang dikirimkan oleh individu kepada otoritas pemungut pajak sebagai alat komunikasi sosial untuk mengetahui jarak sosial antara wajib pajak dan otoritas pemungut pajak. Dalam kaitannya dengan perpajakan, konsep jarak sosial berguna untuk menjelaskan bagaimana individu menempatkan diri di luar jangkauan dan pengaruh otoritas, sehingga otoritas tidak mengerti tuntutan, dan akhirnya menimbulkan konsekuensi ketidakpatuhan wajib pajak. Semakin jauh jarak sosial menandakan bahwa peraturan yang dibuat belum mencerminkan keinginan wajib pajak terkaitdengan keadilan pemungutan, keadilan penetapan tarif, serta kesederhanaan tata cara pemungutan.

Terdapatlima postur motivasi yang diidentifikasi oleh Braithwaite (2007:139) yaitu: 1) commitment, 2) capitulation, 3) resistance, 4) disengagement dan 5) game playing. Commitment dan capitulation menunjukkan orientasi positif wajib pajak terhadap fiskus sedangkan, tiga lainnya menunjukkan orientasi negatif. Pengukuran yang dilakukan oleh Braithwaite kepada tiap individu dengan memberikan daftar pernyataan yang dianggap bisa menjabarkan postur tersebut. 
Commitment adalah cerminan keyakinan wajib pajak akan suatu sistem pajak yang dikehendaki, dan kesadaran wajib pajak terkait obligasi moral untuk membayar pajak dengan benar. Capitulation (penyerahan) menggambarkan individu yang menerima fiskus sebagai pihak yang memiliki legitimasi serta melaksanakan berbagai aturan dengan benar. Sedangkan resistance adalah suatu perlawanan terbuka terhadap otoritas pajak melalui kritik dan ajakan kepada wajib pajak lain untuk lebih berhati-hati dan memperjuangkan hak sebagai wajib pajak. Disengagement merupakan bentuk lain dari resistensi yang lebih dalam, melibatkan keterpisahan psikologis dari otoritas pajak akibat adanya kekecewaan yang meluas. Game playing mewakili perilaku yang lebih imajinatif dan praktik untuk menghindar dari ketentuan dengan cara "memainkan aturan".

\section{Kepatuhan Wajib Pajak}

Menurut Kamus Besar Bahasa Indonesia, kepatuhan adalah sifat patuh, kaetaatan. Menurut Safri Nurmantu (2005:86) pengertian kepatuhan diartikan bahwa Wajib Pajak memenuhi semua kewajiban perpajakan dan melaksanakan hak dan perpajakannya. Terdapat dua macam kepatuhan, yakni kepatuhan formal dan kepatuhan material . Kepatuhan formal adalah suatu keadaan dimana Wajib Pajak memenuhi kewajiban perpajakannya secara formal sesuai dengan ketentuan dalam undang-undang perpajakan. Misalnya, ketentuan batas waktu penyampaiana Surat Pemberitahuan Pajak Penghasilan (SPT PPh) Tahunan tanggal 31Maret. Apabila Wajib Pajak telah telah melaporkan SPT PPh sebelum atau pada tanggal 31 Maret maka Wajib Pajak telah memenuhi kepatuhan formal, akan tetapi isinya belum tentu memenuhi ketentuan material, yaitu suatukeadaan dimana Wajib Pajak secara subtantif memenuhi semua ketentuan material perpajakan, yakni sesuai isi dan jiwa undang-undang perpajakan. Kepatuhan material dapat meliputi kepatuhan 
formal. Wajib Pajak yang memenuhi kepatuhan material adalah Wajib Pajak yang mengisi dengan jujur, lengkap, dan benar SPT sesuai dengan ketentuan dan menyampaiakannya ke kantor pelayanan pajak sebelum batas waktu berakhir.

Undang-undang tidak pernah menegaskan siapa dan bagaimana kriteria dari Wajib Pajak yang tergolong patuh. Kriteria WP Patuh hanya diatur dalam Keputusan Menteri Keuangan Nomor 235/kmk.03/2003. Hal ini pun hanya kriteria yang dikaitkan dengan masalah pengambilan pendahuluan kelebihan pembayaran pajak sebagaimana diatur dalam Pasal 1 antara lain :

a. Tepat waktu dalam menyampaikan SPT dalam 2 tahun terakhir;

b. Dalam tahun terakhir penyampaian SPT Masa yang terlambat tidak lebih dari 3 masa pajak untuk setiap jenis pajak dan tidak berturut-turut;

c. SPT Masa yang terlambat sebagaimana dimaksud dalam hurufbtelah disampaikan tidak lewat dari batas waktu penyampaian SPT Masa masa pajak berikutnya;

d. tidak mempunyai tunggakan pajak untuk semua jenis pajak :

1) kecuali telah memperoleh izin untuk mengangsur ataumenunda pembayaran pajak;

2) tidak termasuk tunggakan pajak sehubungan dengan STP yang diterbitkan untuk 2 (dua) masa pajak terakhir;

e. tidak pernah dijatuhi hukuman karena melakukan tindak pidana di bidang perpajakan dalam jangka waktu 10 (sepuluh) tahun terakhir; dan

f. laporan keuangan diaudit oleh akuntan publik atauBadanPengawasan Keuangan dan Pembangunan harus denganpendapatwajar tanpa pengecualian atau dengan pendapat wajar dengan pengecualian sepanjang pengecualian tersebut tidak mempengaruhi laba rugi fiskal. 


\section{Metode Penelitian}

Penelitian ini menggunakan tipe penelitian deskriptif dengan pendekatankuantitatifvariabel dan indikator penelitian diukur dengan skala likert yang disajikan dalam tabel berikut:

Tabel 1

Variabel, Indikator dan skala pengukuran

\begin{tabular}{|c|c|c|c|c|}
\hline $\begin{array}{c}\text { Variabe } \\
1\end{array}$ & Indikator & Sub Indikator & $\begin{array}{c}\text { Skala } \\
\text { Penguku } \\
\text { ran }\end{array}$ & Instrumen \\
\hline $\begin{array}{l}\text { Commit } \\
\text { ment } \\
\text { X1 }\end{array}$ & $\begin{array}{l}\text { Perilaku wajib } \\
\text { pajak secara } \\
\text { sadar } \\
\text { berkeinginan } \\
\text { untuk merasa } \\
\text { terlibat dengan } \\
\text { misi otoritas } \\
\text { pajak }\end{array}$ & $\begin{array}{l}\text { 1. Melaksanaka } \\
\text { n hak \& } \\
\text { kewajiban } \\
\text { sebagai } \\
\text { wajib pajak } \\
\text { tanpa } \\
\text { paksaan. } \\
\text { 2. Membayar } \\
\text { pajak } \\
\text { merupakan } \\
\text { sebuah } \\
\text { pengabdian }\end{array}$ & Interval & Kuesioner \\
\hline $\begin{array}{c}\text { Capitulati } \\
\text { ont } \\
\text { X2 }\end{array}$ & $\begin{array}{l}\text { Menerima } \\
\text { peraturan } \\
\text { yang } \\
\text { diterapkan } \\
\text { otoritas pajak } \\
\text { tanpa harus } \\
\text { merasa terlibat } \\
\text { dengan } \\
\text { otoritas pajak }\end{array}$ & $\begin{array}{l}\text { 1. Telah } \\
\text { membayar } \\
\text { pajak sesuai } \\
\text { peraturan. } \\
\text { 2. Tidak } \\
\text { mengharap } \\
\text { penghargaan } \\
\text { atas } \\
\text { kepatuhan } \\
\text { membayar } \\
\text { pajak. }\end{array}$ & Interval & Kuesioner \\
\hline $\begin{array}{c}\text { Resistan } \\
\text { ce } \\
\text { X3 }\end{array}$ & $\begin{array}{l}\text { Adanya } \\
\text { perlawanan } \\
\text { terbuka }\end{array}$ & $\begin{array}{l}\text { 1. Meragukan } \\
\text { kinerja } \\
\text { otoritas }\end{array}$ & Interval & Kuesioner \\
\hline
\end{tabular}


Pengaruh Postur Motivasi Ditinjau dari Commitment, Capitulation...

\begin{tabular}{|c|c|c|c|c|}
\hline & $\begin{array}{l}\text { terhadap } \\
\text { otoritas pajak }\end{array}$ & $\begin{array}{l}\text { pajak. } \\
\text { 2. Menganggap } \\
\text { otoritas } \\
\text { pajak telah } \\
\text { berlaku tidak } \\
\text { adil }\end{array}$ & & \\
\hline $\begin{array}{c}\text { Disenga } \\
\text { gement } \\
\text { X4 }\end{array}$ & $\begin{array}{l}\text { Melibatkanket } \\
\text { erpisahan } \\
\text { psikologis dari } \\
\text { otoritas pajak }\end{array}$ & $\begin{array}{l}\text { 1. Menunjukka } \\
\text { n sikap tidak } \\
\text { kooperatif } \\
\text { saat adanya } \\
\text { pemeriksaan } \\
\text { pajak } \\
\text { 2. Tidak } \\
\text { menjalin } \\
\text { komunikasi } \\
\text { yang baik } \\
\text { dengan } \\
\text { otoritas } \\
\text { pajak }\end{array}$ & Interval & Kuesioner \\
\hline $\begin{array}{c}\text { Game } \\
\text { Playing } \\
\text { X5 }\end{array}$ & $\begin{array}{l}\text { Perilaku untuk } \\
\text { menghindar } \\
\text { dari ketentuan } \\
\text { pajak }\end{array}$ & $\begin{array}{l}\text { 1. Mengurangi } \\
\text { dasar } \\
\text { penetapan } \\
\text { pajak } \\
\text { 2. Melakukan } \\
\text { pelimpahan } \\
\text { pajak }\end{array}$ & Interval & Kuesioner \\
\hline $\begin{array}{c}\text { Kepatu } \\
\text { han } \\
\text { Wajib } \\
\text { pajak } \\
\text { Y }\end{array}$ & $\begin{array}{l}\text { Kepemilikan } \\
\text { NPWP }\end{array}$ & $\begin{array}{l}\text { 1. Mendaftar } \\
\text { secara } \\
\text { sukarela } \\
\text { 2. Menenuhi } \\
\text { syarat } \\
\text { mendapatka } \\
\text { n NPWP }\end{array}$ & Interval & Kuesioner \\
\hline
\end{tabular}




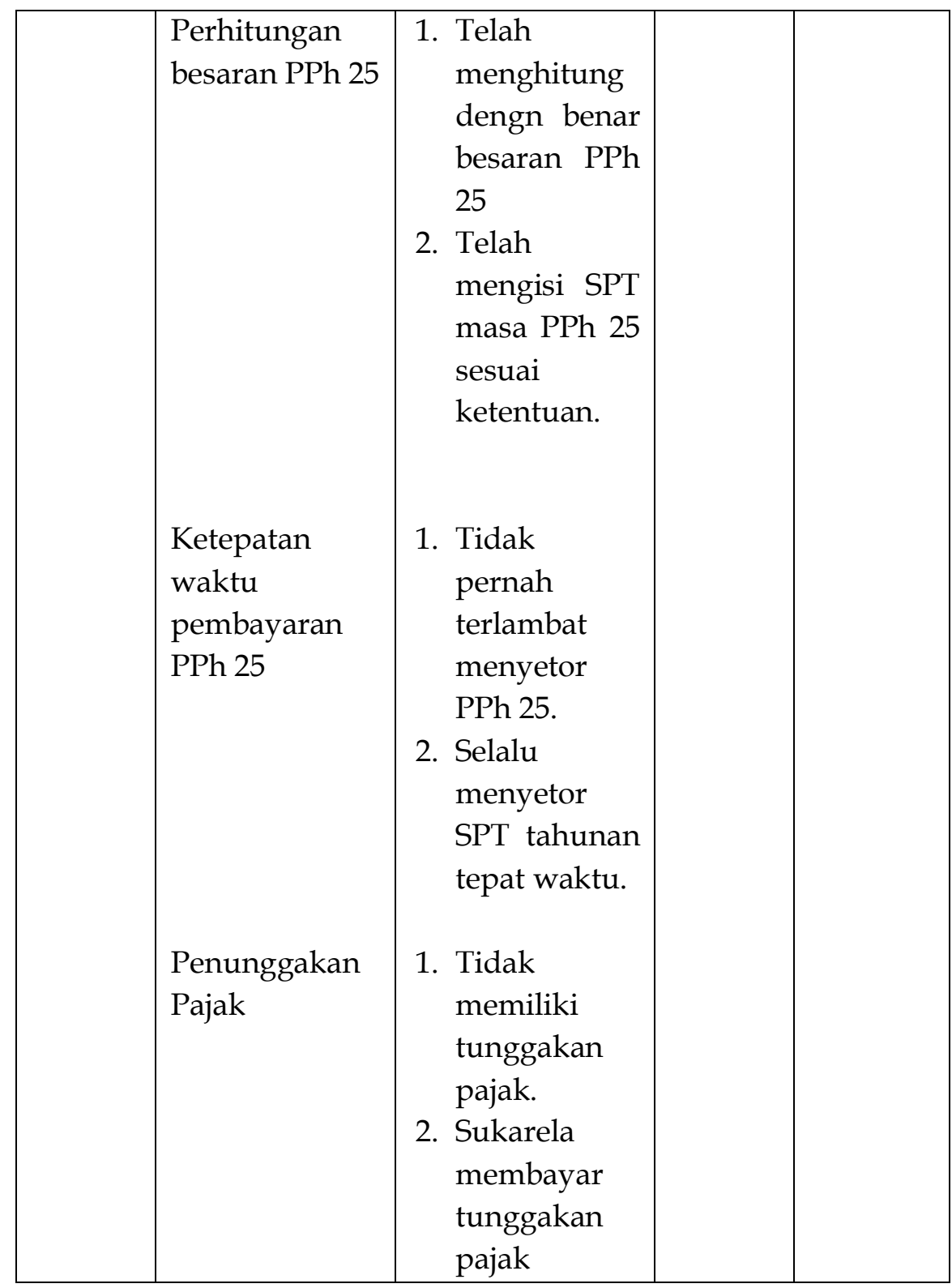

Populasi yang digunakan dalam penelitian ini merupakan WP Orang Pribadi yang memiliki usaha mikro, kecil, menengah di Jombang.Berdasarkan data statistik yang di dapatkan dari DinasKoperasi dan UMKM Kabupaten Jombang, jumlah wajib pajak orang pribadi yang memiliki UMKM yang 
ada diKabupaten Jombang hingga tahun 2014 sebanyak 29.093 (http://dinkop-umkm.dievo.org).Berdasarkanrumus

Slovin(Riduwan, 2006:65) dengan margin of error sebesar 10\% maka jumlah sampel yang diambil dalam penelitian ini adalah sebanyak 99 wajib pajak orang pribadi.

Jenis data yang digunakan dalam penelitian in merupakan data kuantitatif yang diperoleh melalui penelitian lapangan (field Research)dankepustakaan (Library Research).Metode analisis yang dilakukan adalah regresi linear berganda variabel Dummy. Regresi ini memprediksi besar variabel tergantung menggunakan data variabel bebas adalah variabel dummy. Variabel dummy adalah variabel yang digunakan untuk membuat kategori data yang bersifat kualitatif (nominal).

\section{Gambaran Umum Objek Penelitian}

Penelitian ini memfokuskan pada WP orang pribadi yang memiliki usaha sendiri atau UMKM di kabupaten Jombang. Wajib pajak orang pribadi sektor UMKM setiap tahun mengalami peningkatan, dibuktikan dengan lahirnya banyakUMKM baru di Jombang.Tercatat pada arsip Dinas Koperasi dan UMKM Jombang terdapat 29.093 UMKM.UMKM baik perseorangan maupun badan yang memenuhi syarat sebagai Wajib Pajak, wajib mendaftarkan diri ke KPP atau K2KP untuk memperoleh NPWP. UMKM perseorangan yang wajib memiliki NPWP adalah yang telah memenuhi persyaratan subjektif berupa orang pribadi dan syarat objektif berupa memiliki penghasilan yang akan dikenakan pajak melebihi Penghasilan Tidak Kena Pajak (PTKP).

\section{Hasil Penelitian}

\section{Uji Regresi Linier Berganda}

Analisis regresi linier berganda digunakan untuk mengetahui suatu hubungan fungsional variabel dependendengan variabel independendan diperoleh hasil sebagai berikut 
Tabel 2

Uji Regresi Linier Berganda

Coefficients $^{a}$

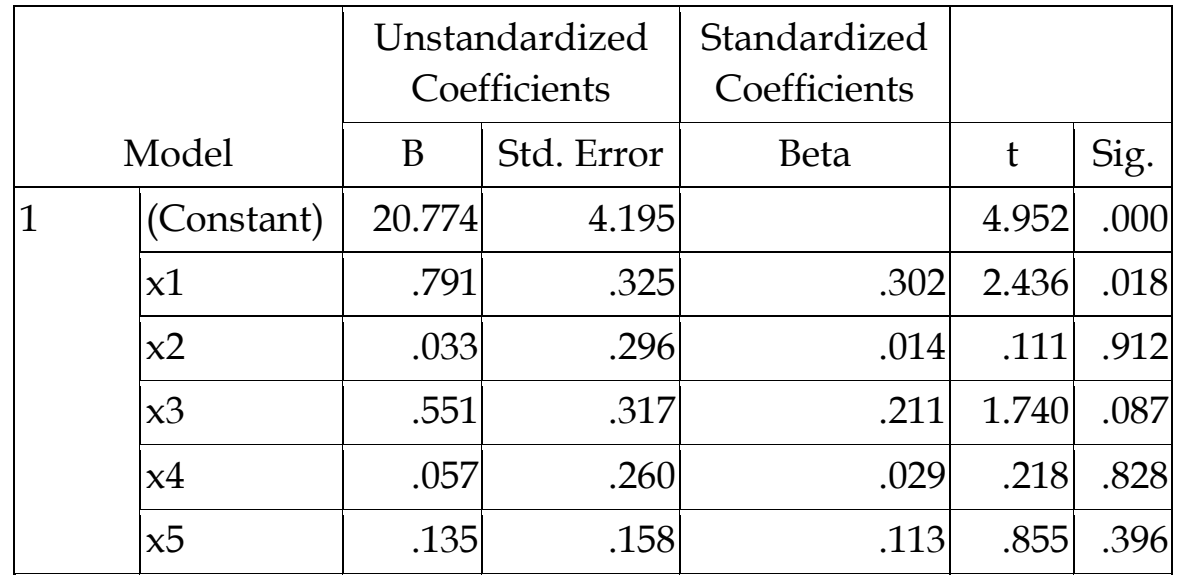

a. Dependent Variable: y

Dari tabel diatas didapatkan model regresi yang terbentuk dinyatakan sebagai berikut :

$$
\begin{gathered}
Y=\alpha+\beta_{1} X_{1}+\beta_{2} X_{2}+\beta_{3} X_{3}+\beta_{4} X_{4}+\beta_{5} X_{5}+e \\
Y=20,774+0,791 X_{1}+0,033 X_{2}+0,551 X_{3}+0,057 X_{4}+0,135 X_{5}+e
\end{gathered}
$$

Keterangan:

$Y=$ kepatuhan wajib pajak orang pribadi

$\alpha=$ Konstanta

$\beta 1=$ Koefisien regresi commitment

$\beta 2=$ Koefisien regresi capitulation

$\beta 3=$ Koefisien regresi resistance

$\beta 4=$ Koefisien regresi disengagement

$\beta 5=$ Koefisien regresigame playing

$\mathrm{X} 1=$ commitment

$\mathrm{X} 2$ = capitulation

$\mathrm{X} 3=$ resistance

$\mathrm{X} 4=$ disengagement

$\mathrm{X} 5=$ game playing

Berdasarkan hasil persamaan regresi, didapatkan nilai konstanta sebesar 20,774.Koefisien regresi variabel commitment (X1) sebesar 0,791 artinya kepatuhan wajib pajak orang pribadi (Y) akan mengalami peningkatan sebesar 0,791 jika X1 
mengalami peningkatan sebesar 1.Koefisien regresi variabel capitulation (X2) sebesar 0,033 artinya kepatuhan wajib pajak orang pribadi $(\mathrm{Y})$ akan mengalami peningkatan sebesar 0,033 jika X2 mengalami peningkatan sebesar 1 . Koefisien regresi variabel resistane (X3) sebesar 0,551 artinya kepatuhan wajib pajak orang pribadi $(\mathrm{Y})$ akan mengalami peningkatan sebesar 0,551 jika X3 mengalami peningkatan sebesar 1.Koefisien regresi variabel disengagement (X4) sebesar 0,057 artinya kepatuhan wajib pajak orang pribadi (Y) akan mengalami peningkatan sebesar 0,057 jika X4 mengalami peningkatan sebesar 1. Koefisien regresi variabel game playing (X5) sebesar 0,135 artinya kepatuhan wajib pajak orang pribadi (Y) akan mengalami peningkatan sebesar 0,135 jika X1 mengalami peningkatan sebesar 1 .

Hal ini dapat diartikan bahwa commitment, capituation, resistance, disengagement, dan game playing terhadap kepatuhan wajib pajak orang pribadi cukup signifikan.

\section{Uji Hipotesis}

a. Uji Signifikan Parsial (Uji T)

Uji statistik $t$ berguna untuk menguji pengaruh dari masing - masingvariabel independen secara parsial terhadap variabel dependen.Untuk mengetahui ada tidaknya pengaruh masing-masing variabel independen secara parsial terhadap variabel dependen dapat dilihatpada tinglat signifikansi 0,05 dan df (degree of freedom) : n-k = 66-6 = 60, maka diperoleh $t_{\text {tabel }} 1,670$.

\section{Tabel 3}

\section{Uji signifikan $t$}

\section{Coefficients ${ }^{a}$}

\begin{tabular}{|c|c|c|}
\hline Model & $\begin{array}{c}\text { Unstandardized } \\
\text { Coefficients }\end{array}$ & $\begin{array}{c}\text { Standar } \\
\text { dized } \\
\text { Coeffici } \\
\text { ents }\end{array}$ \\
\hline
\end{tabular}




\begin{tabular}{|l|l|r|r|r|r|r|}
\hline \multicolumn{2}{|c|}{} & \multicolumn{1}{c|}{ B } & Std. Error & Beta & \multicolumn{1}{c|}{$\mathrm{t}$} & \multicolumn{1}{c|}{ Sig. } \\
\hline \multirow{3}{*}{1} & (Constant) & 20.774 & 4.195 & & 4.952 & .000 \\
\cline { 2 - 8 } & $\mathrm{x} 1$ & .791 & .325 & .302 & 2.436 & .018 \\
\cline { 2 - 8 } $\mathrm{x} 2$ & .033 & .296 & .014 & .111 & .912 \\
\hline \multirow{2}{*}{$\mathrm{x} 3$} & .551 & .317 & .211 & 1.640 & .087 \\
\cline { 2 - 8 } & $\mathrm{x} 4$ & .057 & .260 & .029 & .218 & .828 \\
\hline & $\mathrm{x} 5$ & .135 & .158 & .113 & .855 & .396 \\
\hline
\end{tabular}

a. Dependent Variable: $y$

Dari tabel di atas dapat diketahui tingkat signifikan untuk masing-masing variabel bebas, yaitu :

1. Pengaruh commitment terhadap kepatuhan wajib pajak

Variabel bebas commitment (X1) diperoleh $t_{\text {hitung }}>t_{\text {tabel }}$ $(2,436>1,67)$. Dengan demikian berarti Ho ditolak dan Ha diterima. Demikian pula diperoleh nilai signifikan sebesar $0,018<0,05$ yang berarticommitmen berpengaruh secara signifikan terhadap kepatuhan wajib pajak orang pribadi.Hasil perhitungan diatas dapat digambarkan sebagai berikut :

\section{Gambar 1}

\section{Hasil Uji t Commitment}

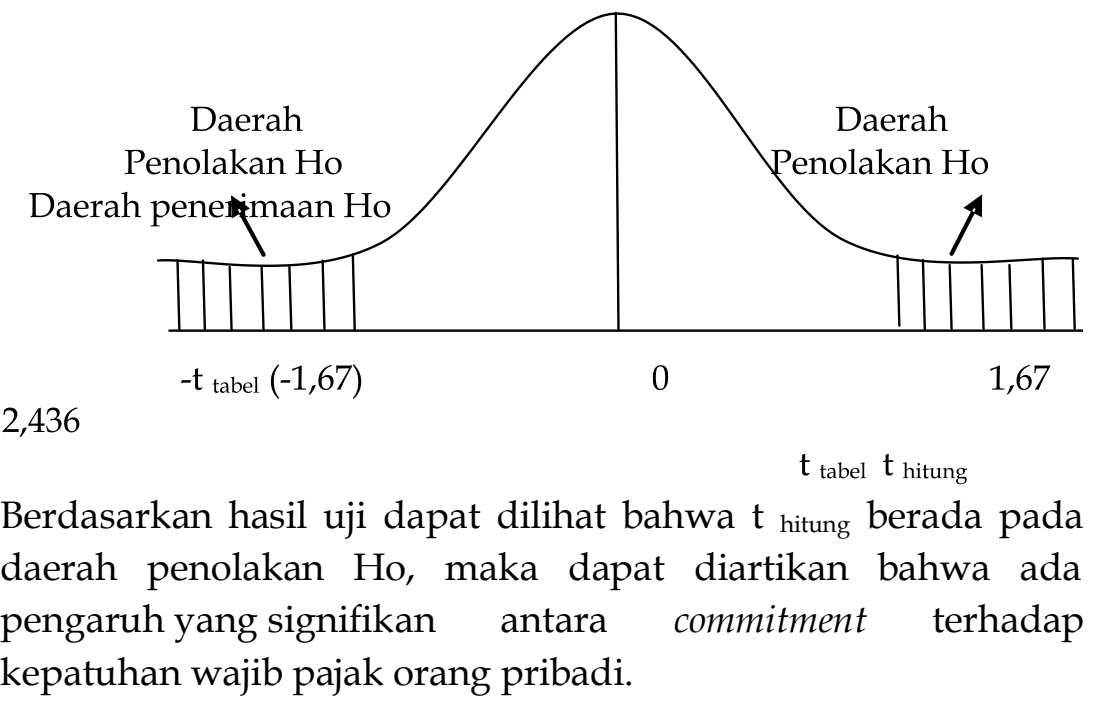


2. Pengaruh capitulation terhadap kepatuhan wajib pajak

Variabel bebas capitulation (X2) diper oleh $t_{\text {hitung }}<t_{\text {tabel }}$ $(0,111<1,67)$. Dengan demikian berarti Ho diterima dan Ha ditolak. Demikian pula diperoleh nilai signifikan sebesar $0,912>0,05$ yang berarticapitulatin tidak berpengaruh secara signifikan terhadap kepatuhan wajibpajakorangpribadi. Hasil perhitungan diatas dapat digambarkan sebagai berikut:

\section{Gambar 2}

\section{Hasil Uji t Capitulation}

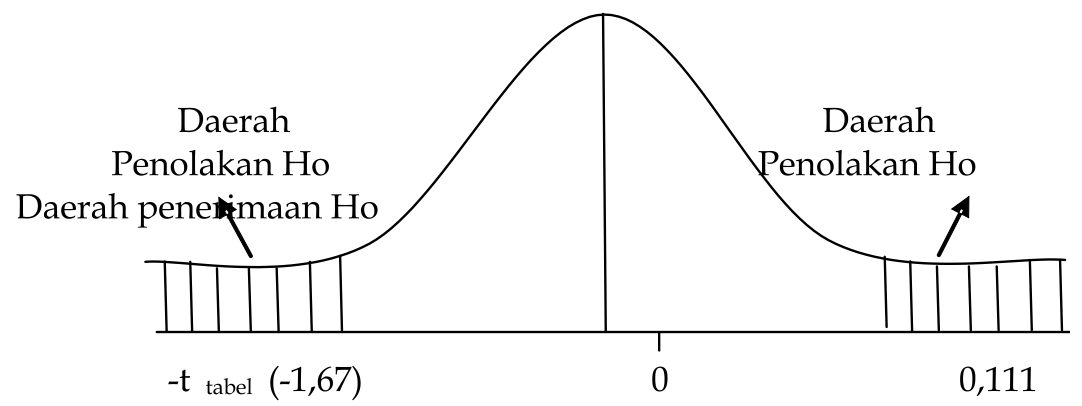

1,67

$$
\mathrm{t}_{\text {hitung }} \quad \mathrm{t}_{\text {tabel }}
$$

Berdasarkan hasil uji dapat dilihat bahwa $t$ hitung berada pada daerah penerimaan Ho, maka dapat diartikan bahwa tidak ada pengaruh yangsignifikan antara capitulation terhadap kepatuhan wajib pajak orang pribadi.

3. Pengaruh resistance terhadap kepatuhan wajib pajak

Variabel bebas resistance(X3)diperoleh $t_{\text {hitung }}<$ $t_{\text {tabel }}(1,640<1,67)$.Dengan demikian berarti Ho diterima dan Ha ditolak. Demikian pula diperoleh nilai signifikan sebesar 0,087 $>0,05$ yang berarti capitulatin tidak berpengaruh secara signifikan terhadap kepatuhan wajib pajak orang pribadi.Hasil perhitungan diatas dapat digambarkan sebagai berikut : 
Gambar 3

Hasil Uji t resistance

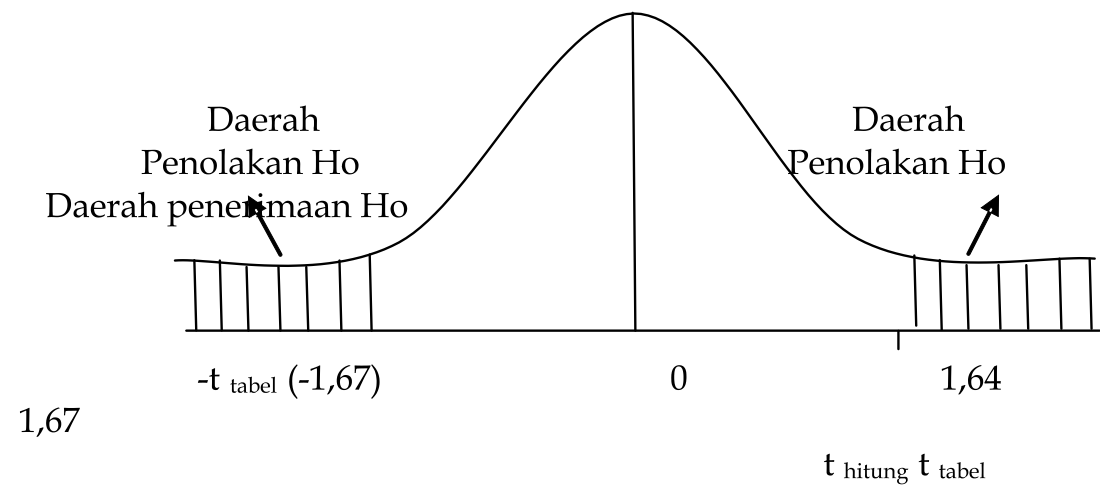

Berdasarkan hasil uji dapat dilihat bahwa $t$ hitung berada pada daerah penerimaan Ho, maka dapat diartikan bahwa tidak ada pengaruh yang signifikan antara resistance terhadap kepatuhan wajib pajak orang pribadi.

4. Pengaruh disengagement terhadap kepatuhan wajib pajak

Variabel bebas disengagement (X4) diperoleh $t_{\text {hitung }}<$ $t_{\text {tabel }}(0,218<1,67)$. Dengan demikian berarti Ho diterima dan Ha ditolak. Demikian pula diperoleh nilai signifikan sebesar 0,828 > 0,05 yang berarticapitulatin tidak berpengaruh secara signifikan terhadap kepatuhan wajib pajak orang pribadi.

Hasil perhitungan diatas dapat digambarkan sebagai berikut:

Gambar 4

Hasil Uji t Disengagement

1,67

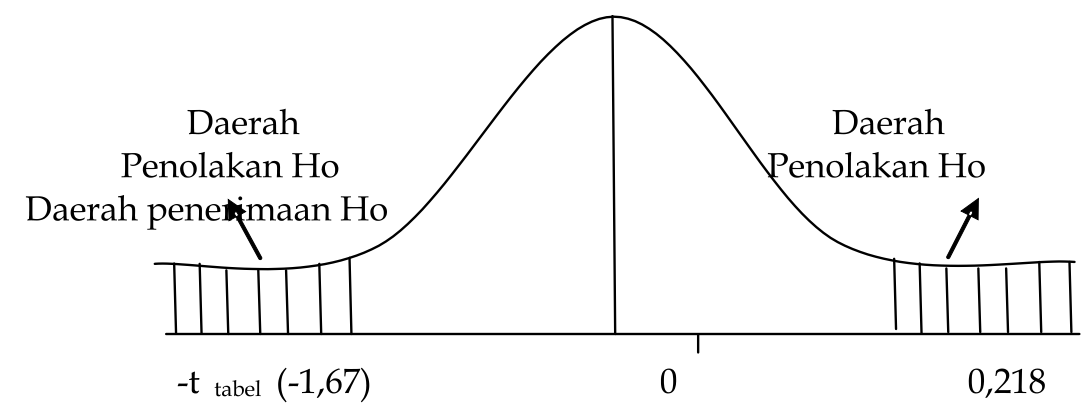


Berdasarkan dapat dilihat bahwa $\mathrm{t}$ hitung berada pada daerah penerimaan Ho, maka dapat diartikan bahwa tidak ada pengaruh yang signifikan antara disengagement terhadap kepatuhan wajib pajak orang pribadi.

5. Pengaruh game playing terhadap kepatuhan wajib pajak

Variabel bebas game playing (X5) diper oleh $t_{\text {hitung }}<t_{\text {tabel }}$ $(0,855<1,67)$. Dengan demikian berarti Ho diterima dan Ha ditolak. Demikian pula diperoleh nilai signifikan sebesar 0,396 > 0,05 yang berarti capitulatin tidak berpengaruh secara signifikan terhadap kepatuhan wajib pajak orang pribadi.Hasil perhitungan diatas dapat digambarkan sebagai berikut :

\section{Gambar 5}

\section{Hasil Uji t Game Playing}

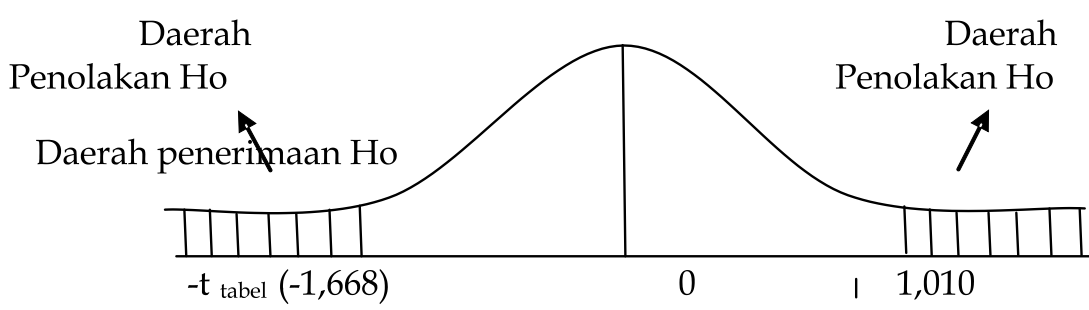

1,668

$$
t_{\text {hitung }} \quad t_{\text {tabel }}
$$

Berdasarkan hasil uji dapat dilihat bahwa $t$ hitung berada pada daerah penerimaan Ho, maka dapat diartikan bahwa tidak ada pengaruh yang signifikan antara game playing terhadap kepatuhan wajib pajak orang pribadi.

\section{b. Uji Secara Simultan (Uji F)}

Uji statistik $F$ bertujuan untuk mengetahui pengaruh secara bersama-sama atau simultan variabel independen terhadap variabeldependen atau terikat. Adapun ketentuan untuk pengujian hipotesis secara simultan, yaitu : Jika $\mathrm{F}_{\text {hitung }}<\mathrm{F}_{\text {tabel, }}$ maka Ho diterima dan Ha ditolak Jika $\mathrm{F}_{\text {hitung }}>\mathrm{F}_{\text {tabel, }}$ maka Ho ditolak dan Ha diterima 
Tingkat signifikasi yang diharapkan adalah sebesar $5 \%$ dengan degree of freedom atau df1 $=\mathrm{k}-1$ dan df2 $=\mathrm{n}-$ kdiperoleh $\mathrm{F}_{\text {tabel }}=2,37 \quad(\mathrm{df1}=6-1, \mathrm{df2}=66-6)$. Hasil perhitungan uji regresi simultan dengan program SPSS 17 adalah sebagai berikut :

\section{Tabel 4 \\ Hasil Uji F}

ANOVA $^{b}$

\begin{tabular}{|l|l|r|r|r|r|r|}
\hline \multicolumn{2}{|c|}{ Model } & $\begin{array}{c}\text { Sum of } \\
\text { Squares }\end{array}$ & \multicolumn{1}{c|}{ df } & Mean Square & F & Sig. \\
\hline 1 & Regression & 80.380 & 5 & 16.076 & 2.466 & .04 \\
& & & & & & $3 \mathrm{a}$ \\
\cline { 2 - 7 } & Residual & 391.211 & 60 & 6.520 & & \\
\cline { 2 - 7 } & Total & 471.591 & 65 & & & \\
\hline
\end{tabular}

a. Predictors: (Constant), x5, x3, x1, x2, x4

b. Dependent Variable: y

Berdasarkan tabel diatas, dapat diketahui bahwa tingkat signifikasi $(0,043)$ yang lebih kecil dari angka signifikan yang ditolelir $\quad(0,05)$ maka Ho ditolak dan menerima Ha. Nilai

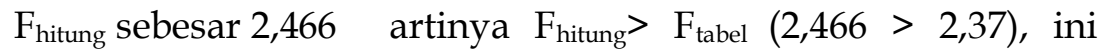
menjelaskan berarti Ho ditolak dan menerima Ha, artinya bahwa commitment, capitulation, resistance, disengagement, dan game playing secara simultan berpengaruh signifikan terhadap kepatuhan wajib pajak orang pribadi.

\section{E. Pembahasan Hasil Penelitian}

Commitment berpengaruh terhadap kepatuhan wajib pajak orang pribadi, hasil perhitungan signifikan $t$ menunjukkan bahwa nilai $t_{\text {hitung }} 2,436$ lebih besar dari $t_{\text {tabel }} 1,67$ dan nilai signifikannya 0,018 lebih kecil probabilitas signifikan $a=0,05$. Maka Ho ditolak dan Ha diterima, sehingga dapat dikatakan bahwa commitment berpengaruh signifikan terhadap kepatuhan wajib pajak orang pribadi. Hasil ini tidak sejalan dengan penelitian Yenni Mangonting (2013) yang menyebutkan 
bahwa commitment berpengaruh tidak signifikan terhadap kepatuhan wajib pajak orang pribadi.

Dari hasil uji statistik parsial, variabel commitment adalah satu-satunya yang mempengaruhi kepatuhan wajib pajak orang pribadi yang yang memiliki usaha. Ini menunjukkan bahwa pelaku usaha mikro, kecil dan menengah merasa membayar pajak adalah hal yang benar dan tanggung jawab sesuai dengan perhitungan dan kondisi sebenarnya. Semakin baik komitmen wajib pajak, semakin patuh pajak tersebut.

Capitulation berpengaruh terhadap kepatuhan wajib pajak orang pribadi, hasil perhitungan signifikan $t$ menunjukkan bahwa nilai $t_{\text {hitung }}$ 0,111 lebih kecil dari $t_{\text {tabel }}$ 1,67 dan nilai signifikannya 0,912 lebih besar probabilitas signifikan $a=0,05$. Maka Ho diterima dan Ha ditolak, sehingga dapat dikatakan bahwa capitulation tidak berpengaruh signifikan terhadap kepatuhan wajib pajak orang pribadi. Hasil ini sejalan dengan penelitian Yenni Mangonting (2013) yang menyebutkan bahwa capitulation secara parsial tidak berpengaruh signifikan terhadap kepatuhan wajib pajak orang pribadi.

Dari hasil uji statistik parsial, variabel capitulation tidak berpengaruh terhadap kepatuhan wajib pajak orang pribadi. Namun dari hasil penelitian ada responden yang setuju terhadap variabel capitulation. Hasil ini menunjukkan tanpa didasari variabel capitulation yang jelas, para pelaku usaha mikro, kecil dan menengah tampaknya melakukan kewajiban perpajakannya semata-mata hanya karena ada aturan yang ditetapkan.

Resistance berpengaruh terhadap kepatuhan wajib pajak orang pribadi, hasil perhitungan signifikan $\mathrm{t}$ menunjukkan bahwa nilai $t_{\text {hitung }} 1,640$ lebih kecil dari $t_{\text {tabel }} 1,67$ dan nilai signifikannya 0,087 lebih besar probabilitas signifikan $a=0,05$. Maka Ho diterima dan Ha ditolak, sehingga dapat dikatakan bahwa resistance tidak berpengaruh signifikan terhadap kepatuhan wajib pajak orang pribadi. Hasil ini sejalan dengan penelitian Yenni Mangonting (2013) yang menyebutkan bahwa 
resistance secara parsial tidak berpengaruh signifikan terhadap kepatuhan wajib pajak orang pribadi.

Dari hasil uji statistik parsial, variabel resistance tidak berpengaruh terhadap kepatuhan wajib pajak orang pribadi. Namun dari hasil penelitian ada responden yang setuju terhadap variabel resistance. Hasil ini menunjukkan tanpa didasari variabel resistance yang jelas, tampaknya kegagalan untuk melaporkan dan menyetorkan pajak yang berimplikasi pada sanksi, denda dan pemeriksaan berusaha dihindari supaya social distance yang sudah terbentuk tidak berubah.

Disengagement berpengaruh terhadap kepatuhan wajib pajak orang pribadi, hasil perhitungan signifikan $t$ menunjukkan bahwa nilai $t_{\text {hitung }}$ 0,218 lebih kecil dari $t_{\text {tabel }}$ 1,67 dan nilai signifikannya 0,828 lebih besar probabilitas signifikan $a=0,05$. Maka Ho diterima dan Ha ditolak, sehingga dapat dikatakan bahwa disengagement tidak berpengaruh signifikan terhadap kepatuhan wajib pajak orang pribadi. Hasil ini sejalan dengan penelitian Yenni Mangonting (2013) yang menyebutkan bahwa disengagement secara parsial tidak berpengaruh signifikan terhadap kepatuhan wajib pajak orang pribadi.

Dari hasil uji statistik parsial, variabel disengagement tidak berpengaruh terhadap kepatuhan wajib pajak orang pribadi. Namun dari hasil penelitian ada responden yang setuju terhadap variabel disengagement. Hasil ini menunjukkan tanpa didasari variabel disengagement yang jelas, para pelaku usaha ini tampaknya sebisa mungkin menghindar dari kemungkinan diperiksa oleh fiskus. Braithwaite (2007:139) menyatakan bahwa disengagement pada tingkat yang lebih dalam justru semakin membuat wajib pajak berusaha memiliki jarak sosial yang semakin jauh, bahkan wajib pajak memilih supaya tidak menjadi perhatian atau deteksi fiskus.

Game playing berpengaruh terhadap kepatuhan wajib pajak orang pribadi, hasil perhitungan signifikan $t$ menunjukkan bahwa nilai $t_{\text {hitung }} 0,855$ lebih kecil dari $t_{\text {tabel }} 1,67$ dan nilai signifikannya 0,396 lebih besar probabilitas signifikan $a=0,05$. Maka Ho diterima dan Ha ditolak, sehingga dapat 
dikatakan bahwa game playing tidak berpengaruh signifikan terhadap kepatuhan wajib pajak orang pribadi. Hasil ini tidak sejalan dengan penelitian Yenni Mangonting (2013) yang menyebutkan bahwa game playing secara parsial berpengaruh signifikan terhadap kepatuhan wajib pajak orang pribadi.

Dari hasil uji statistik parsial, variabel game playing tidak berpengaruh terhadap kepatuhan wajib pajak orang pribadi. Namun dari hasil penelitian ada responden yang setuju terhadap variabel game playing. Hasil ini menunjukkan tanpa didasari variabel game playing yang jelas, para pelaku usaha mikro, kecil dan menengah lebih mendasarkan motivasi membayar pajak karena melihat peluang untuk membayar pajak serendah mungkin tanpa melanggar aturan pajak.

Pada hipotesis keenam (H06) yaitu postur commitment, capitulatin, resistance, disengagement,game playingberpengaruh terhadap kepatuhan wajib pajak orang pribadi, hasil perhitungan simultan $\mathrm{F}$ menunjukkan bahwa nilai $\mathrm{F}_{\text {hitung }}$ 2,466 lebih besar dari $\mathrm{F}_{\text {tabel }}$ 2,37 dan nilai signifikannya 0,043 lebih besar standart signifikan $\alpha=0,05$. Maka Ho diterima dan Ha ditolak, sehingga dapat dikatakan bahwa commitment, capitulatin, resistance, disengagement, dan game playing berpengaruh signifikan terhadap kepatuhan wajib pajak orang pribadi. Hasil ini sejalan dengan penelitian Yenni Mangonting (2013) yang menyebutkan bahwa postur motivasi (commitment, capitulatin, resistance, disengagement,game playing) secara simultan berpengaruh signifikan terhadap kepatuhan wajib pajak orang pribadi.

Hal ini menunjukkan bahwa wajib pajak mempunyai motivasi untuk berkomitmen melaksanakan kewajiban pajak dan mentaati peraturan perpajakan yang berlaku, tetapi kemudian dipengaruhi faktor lain, seperti besaran pajak, denda, pemeriksaan. Maka muncul perlawanan terbuka terhadap otoritas pajak (resistance), dan timbul ketidakcocokan dengan otoritas pajak dan ketidakpedulian (disengagement) dan muncul keinginan untuk melakukan perencanaan pajak (game playing). 


\section{F. Simpulan Dan Saran}

\section{Simpulan}

Penelitian ini bertujuan untuk menganalisis pengaruh dari postur motivasi (commitment, capitulation, resistance, disengagement, game playing) dan tingkat pendidikan terhadap kepatuhan wajib pajak orang pribadi, Berdasarkan hasil penelitian yang telah dilakukan dapat diambil kesimpulan sebagai berikut :

a) Berdasarkan uji statistik dan pembahasan dalam penelitian ini, maka postur motivasi berupa variabel capitulation $(0,648$ $<0,05)$, resistance $(0,396<0,05)$, disengagement $(0,984<0,05)$, dan game playing $(0,317<0,05)$ secara parsial tidak mempengaruhi kepatuhan wajib pajak orang pribadi dalam melaksanakan kepatuhan pajak. Variabel commitment $(0,038$ $<0,05$ )secara parsial mempengaruhi kepatuhan wajib pajak orang pribadi dalam melaksanakan kepatuhan pajak. Ini menunjukkan bahwa para pelaku usaha mikro, kecil dan menengah merasa membayar pajak adalah hal yang benar dan ia bertanggung jawab terhadap terhadap kewajibannya dengan membayar pajak sesuai dengan perhitungan dan kondisi sebenarnya.

b) Berdasarkan uji statistik dan pembahasan dalam penelitian ini, maka commitment, capitulation, resistance, disengagement, dan game playing $(0,043<0,05)$ secara simultan mempengaruhi kepatuhan wajib pajak orang pribadi dalam melakukan kewajiban pajak.Hal ini menunjukkan bahwa wajib pajak mempunyai motivasi untuk berkomitmen melaksanakan kewajiban pajak dan mentaati peraturan perpajakan, tetapi kemudian dipengaruhi faktor lain, seperti besaran pajak, denda, pemeriksaan. Maka muncul perlawanan terbuka terhadap otoritas pajak (resistance), dan timbul ketidakcocokan dengan otoritas pajak dan ketidakpedulian (disengagement) dan muncul keinginan untuk melakukan perencanaan pajak (game playing). 
Pengaruh Postur Motivasi Ditinjau dari Commitment, Capitulation...

\section{Saran}

Berdasarkan kesimpulan diatas, saran yang dapat diberikan dalam penelitian selanjutnya adalah:

a) Periode penelitian ini terbatas hanya enam bulan saja, penelitian selanjutnya diharapkan menambah periode penelitian agar hasil penelitian lebih akurat.

b) Perhatikan dengan seksama operasional penelitian untuk memberikan hasil yang berkualitas atas instrumen yang diuji dan untuk mengukur variabel yang diteliti.

c) Penelitian selanjutnya disarankan agar lebih memperluas lingkup penelitian, yaitu dengan menambah objek penelitian dan menambah variabel penelitian. 


\section{Daftar Pustaka}

Ali. Mohammad, 2009, Pendidikan untuk Pembangunan Nasional Menuju Bangsa

Indonesia yang Mandiri dan Berdaya Saing Tinggi, Grasindo, Jakarta.

Alm. James, 2013,Expanding the Theory of Tax Compliancefrom Individual Group Mativation. Deparment of Economics, Tulane University New Orlean, LA

Amilin, 2009,AnalisisPengaruh Tingkat Pendidikan dan Jenis Pekerjaan Wajib Pajak Terhadap Motivasi dalam Memenuhi Kewajiban Pajak,UIN Syarif Hidayatullah, Jakarta.

Arikunto.S, 2006, Prosedur Penelitian Suatu Pendekatan Praktik, Rineka Cipta, Jakarta.

Braithwaite.V., Murphy. K., \& Reihart.M, 2007,Taxaxion, Threat, Motivational Postures, and Responsive Regulation. Law and Policy,1.

Dianawati. Susi, 2008,Analisis Pengaruh Motivasi dan Tingkat PendidikanTerhadap Kepatuhan Wajib Pajak, UIN Syarif Hidayatullah Jakarta.

Field. Lars P., \& Bruno S. Frey, 2007,Tax Compliance as the Result of a Psychological Tax Contract: The Role of Incentive and Responsive Regulation. LawE Policy, Vol. 29, No1.

Ghozali.Imam, 2009, Aplikasi Multivariate Dengan Program SPSS. Badan Penerbit Universitas Diponegoro, Semarang.

Guwo. W, 2000,Metodologi Penelitian,Grasindo, Jakarta.

Harinaldi,Prinsip-Prinsip Statistik untuk Teknik dan Sains. Yayasan Obor Indonesia, Jakarta.

Hutagoal. John, 2005,Sekilas tentang Badan Hukum Pendidikan dan Aspek Perpajakan. Berita pajak no 1525/tahun 37. 
Pengaruh Postur Motivasi Ditinjau dari Commitment, Capitulation...

Hutagoal. John, 2007, Perpajakan Isu-Isu Kontenporer,Graha Ilmu, Yogyakarta.

Mangonting.Yenni, 2013,Pengaruh Postur Motivasi Terhadap Kepatuhan Wajib Pajak Orang Pribadi,Universitas Kristen Petra Surabaya.

Nurmantu. Safri, 2005,Pengantar Perpajakan,Yayasan Obor Indonesia, Jakarta.

Nurseto. Cahyo, 2002,Pengaruh Persepsi Tentang Pajak dan Tingkat Pendidikan Terhadap Kesadaran Wajib Pajak, STAN Jakarta.

Riduwan, 2006,Metode dan Teknik Menyusun Tesis,Alfabeta, Bandung.

Sudjana, 2002, Metode Statistika. Tarsito,Bandung.

Sugiyono, 2010,Metode Penelitian Bisnis,Alfabeta, Bandung. 2011, Statistika untuk Penelitian, Alfabeta, Bandung.

Sumarsan. Thomas, 2010,Sistem Pengendalian Manajemen,Indeks, Jakarta

Tongler. B, \& Scheider. F,Attitudes Towards Paying Taxes in Austria.. An Epirical Analysis. Empirica 32 (2), 231-250, 2005

Waluyo, 2011,Perpajakan Indonesia,Salemba Empat ,Jakarta

http://dinkop-umkm.gievo.org. Dinas Koperasi dan UMKM Kabupaten Jombang. Diakses pada 20 Juni 2015

http:/ / pajak.go.id/content/pajak-penghasilan-orang-pribadiuntuk-keadilan. Diaksespada 20 Maret 2015 